\section{A fast way to convert carbon}

Researchers have come up with a biochemical pathway that converts carbon dioxide into useful organic compounds more efficiently than plants can.

A team led by Tobias Erb at the Max Planck Institute for Terrestrial Microbiology in Marburg, Germany, assembled a series of chemical reactions using 17 redesigned enzymes from 9 different organisms. The main enzyme used by plants in photosynthesis makes the process of $\mathrm{CO}_{2}$ fixation relatively slow, but using other enzymes from bacteria, plants and humans, the researchers developed a quicker and more energyefficient pathway.

This process could have many applications, such as boosting $\mathrm{CO}_{2}$ fixation in photosynthetic organisms, the authors say.

Science 354, 900-904 (2016)

\section{MICROBIOME}

\section{Low-fibre diet puts gut at risk}

Mice eating a low-fibre diet have a higher risk of bowel infection, thanks to bacteria that normally live in the gut.

Eric Martens at the University of Michigan Medical School in Ann Arbor and Mahesh Desai, now at the Luxembourg Institute of Health, together with their colleagues, compared the effects of fibre-poor and fibre-rich diets in mice that lacked their own bacteria and were given a mix of 14 species of human gut bacteria. These microbes normally consume carbohydrates from dietary fibre, but without these nutrients, the bacteria instead degraded the mucus barrier that lines the intestinal wall.

Thinning of this protective layer (pictured as indicated

$\Sigma$ by white arrows in the right panel; left panel shows normal layer) exposed the intestinal surface to attack by disease-causing bacteria. More than half of the mice eating a low-fibre diet lost at least $20 \%$ of their body weight after infection with the pathogen Citrobacter rodentium.

Cell 167, 1339-1353 (2016)

\section{GENOMICS \\ DNA reveals history of maize}

Maize (corn) that grew more than 5,000 years ago was genetically more similar to today's maize than to its wild counterpart, suggesting that the plant was already being domesticated.

Nathan Wales and Jazmín Ramos-Madrigal of the University of Copenhagen and their team sequenced the genome of a 5,310-year-old maize cob (Zea mays) excavated in the 1960s in Mexico. They found a gene variant responsible for producing kernels that lack a hard seed coat and are easy to eat - probably the first step in domestication. However, other genes typically found in today's maize were absent, including one that prevents maize ears from shattering when ripe.

Curr. Biol. http://doi.org/btcs (2016)

\section{DEVELOPMENTAL BIOLOGY}

\section{'Mini-guts' made with nerves}

Miniature tissue structures resembling a human intestine with functional nerves can mimic the involuntary contractions that push food through the gut.

James Wells and Michael Helmrath of the Cincinnati Children's Hospital Medical

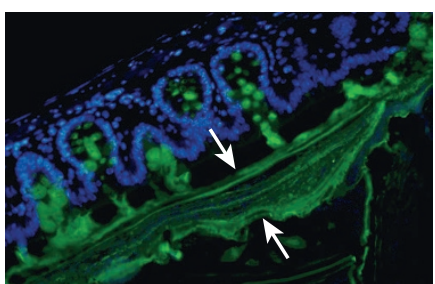

Center in Ohio and their team generated nerve and intestinal cells from human stem cells. They grew the mix for 28 days to make 3D structures, or organoids, that had intrinsic nerve cells. They then transplanted the organoids into mice to form mature nerves. A single electric impulse triggered a prolonged wave of contractions in the organoids that had a nervous system, but did not do so in structures lacking nerves. Using the model, the group identified molecular pathways involved in Hirschsprung's disease, a rare disorder of the large intestine.

These organoids could be used to study other intestinal diseases, the authors say. Nature Med. http://dx.doi. org/10.1038/nm.4233 (2016)

\section{ECOLOGY \\ Ants farm plants in Fiji}

A species of ant in Fiji survives by farming six plant species. The ants nurture seedlings and then live in the cavities of the plants.

Guillaume Chomicki and Susanne Renner of the University of Munich in Germany found that Philidris nagasau ants carry seeds of six species of Squamellaria plant and insert them into cracks in trees, where they germinate (pictured). The ants also fertilize the seeds with their waste, and are only found living near these plants.

Although ants are known to farm fungi, this is the first time they have been found to plant seeds and actively cultivate them. Examining the family trees of relatives of these ants and plants suggests that this mutually dependent

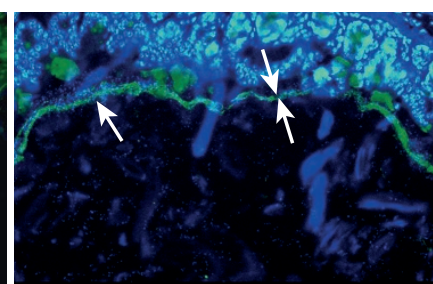

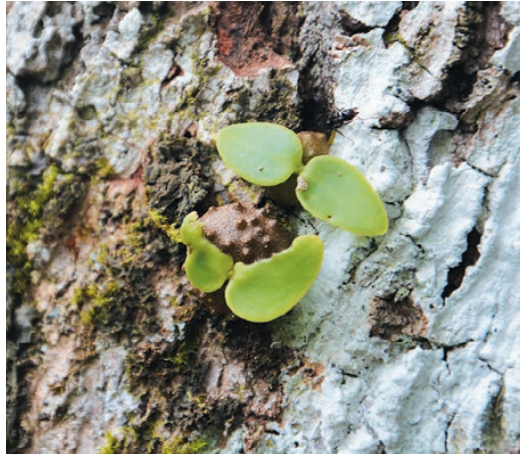

relationship evolved around 3 million years ago.

Nature Plants http://dx.doi.org/ 10.1038/nplants.2016.181(2016)

\section{GENOMICS}

\section{Epidemics marked indigenous DNA}

Epidemics from Europe that killed thousands of indigenous Canadians in the nineteenth century have left their signatures in the genomes of people in Canada today.

Ripan Malhi at the University of Illinois in Urbana-Champaign, Michael DeGiorgio at Pennsylvania State University in University Park and their colleagues sequenced the genomes of 25 modern Tsimshian people, who live in coastal British Columbia and Alaska and are among Canada's First Nations. The authors compared the genomes with the DNA of 25 people who lived in the same region between 6,000 and 1,000 years ago. They found that most of the modern Tsimshian people had different versions of immune-system genes, including an HLA gene, from their ancestors. Moreover, the team found an overall decrease in genetic diversity, which probably signifies a sudden population decline of about 57\% around 175 years ago.

This is close to historical accounts that suggested a $70 \%$ decrease due to a smallpox epidemic.

Nature Commun. 7, 13175 (2016)

\section{$\rightarrow$ NATURE.COM}

For the latest research published by Naturevisit:

www.nature.com/latestresearch 